\title{
Simultaneous HPLC Analysis of Betamethasone and Clotrimazole in Cream Formulations
}

\author{
Adnan Manassra $^{1 *}$, Mustafa Khamis ${ }^{1}$, Magdy el-Dakiky1, Zuhair Abdel-Qader ${ }^{2}$ and Fuad Al-Rimawi ${ }^{1}$ \\ ${ }^{1}$ Faculty of Science and Technology, Al-Quds University, P.O. Box 20002, East Jerusalem \\ ${ }^{2}$ Research and Development Department, Jerusalem Pharmaceutical Co., P.O. Box 3570, Al-Bireh, Palestine
}

\begin{abstract}
An HPLC method for the simultaneous quantitative determination of betamethasone and clotrimazole in cream formulation has been developed. The method utilizes a reversed-phase $\mathrm{C} 18(250 \times 4.0 \mathrm{~mm})$ stationary phase, with a mixture of methanol-acetate buffer-acetonitrile $(33: 27: 40, \mathrm{v} / \mathrm{v})$ as a mobile phase, and spectrophotometric UV detection at $254 \mathrm{~nm}$. The method has been validated for cream formulations containing betamethasone and clotrimazole with linear range of 0.025 to $0.075 \mathrm{mg} / \mathrm{ml}$ for betamethasone with a correlation coefficient of 0.9996 , and linear range of 0.25 to $0.75 \mathrm{mg} / \mathrm{ml}$ for clotrimazole with a correlation coefficient of 1.000 . The results demonstrated that this method is accurate, precise, specific, linear, reliable, sensitive, and fast.
\end{abstract}

Keywords: HPLC; Betamethasone; Clotrimazole; Pharmaceutical preparations

\section{Introduction}

Betamethasone is a potent synthetic glucocorticoid that is widely used for the treatment of inflammation, allergies and other diseases related to glucocorticoid deficiency [1]. Clotrimazole is a chlorinated synthetic imidazole derivative having antifungal and antibacterial activities, which are used in the treatment of some infections [2]. The combination of betamethasone and clotrimazole is used for the treatment of candidiasis, vulvovaginal candidiasis and other species of Candida [3-5] and provides anti-inflammatory action.

In the scientific literature, analysis of betamethasone and clotrimazole has been reported as individual ingredients [1-2,614] and in combination products [15]. Betamethasone has been determined in different pharmaceutical preparations by HPLC [1,67]. Clotrimazole has been determined in different pharmaceutical preparations by: Titration method [2], gas liquid chromatography [8], high performance TLC (HPTLC) [9], micellar electrokinetic chromatography (MEKC) [10] and by HPLC [11-14]. Reversed-phase LC for the simultaneous determination of betamethasone and clotrimazole in cream formulations has been described in the USP [15]. However, sample preparation of the cream in this USP method is time consuming (about one hour), tedious (requires centrifuge and heating). The main objective of this study is, therefore, to develop and validate an HPLC method involving minimum sample preparation, good resolution, reasonable analysis time, good accuracy, high precision, good specificity, good linearity, and excellent reliability.

\section{Material and Methods}

\section{Equipments and settings}

The HPLC measurements were carried out using a Merck Hitachi HPLC (Hitachi, Ltd. Tokyo, Japan) equipped with a manual loop injector that was connected to a photo diode array detector, and a recorder.

An analytical column with $\mathrm{C} 18$ stationary phase $(250 \times 4.0 \mathrm{~mm}$ i.d.) bonded onto $5 \mu \mathrm{m}$ silica gel manufactured by Merck (Darmstadt, Germany) was used for chromatographic separation. Degassing of the mobile phase was performed using Sonnicator (Fisher Scientific FS 220). Instrumental HPLC settings were as follows: flow rate 1.5 $\mathrm{ml} / \mathrm{min}$; injection volume $5 \mu \mathrm{l}$, column temperature ambient; and wavelength $254 \mathrm{~nm}$.

\section{Reagents}

All the active and inactive ingredients of the cream were kindly supplied byJerusalem Pharmaceuticals Co. Ltd., Al-Bireh, Palestine, and were of British Pharmacopoeia (BP) or Untied States Pharmacopoeia (USP) quality, and were used without further purification. Acetonitrile and methanol (HPLC grade) are from J. T Baker (NJ, USA). All other chemicals were of analytical reagent grade and they are from Merck (Darmstadt, Germany). Water used was distilled and deionised by passing through water purification system.

Acetate buffer with a $\mathrm{pH}$ of 6.8 was prepared by dissolving 25.0 $\mathrm{g}$ ammonium acetate in $1000 \mathrm{ml}$ of distilled deionised water. Diluent was prepared by mixing $990 \mathrm{ml}$ of methanol and $10 \mathrm{ml}$ of acetic acid. The mobile phase, standard and sample solutions were filtered using $0.45 \mu \mathrm{m}$ microporous filters type polyamid.

\section{Standards and sample preparation}

A standard solution having $0.05 \mathrm{mg} / \mathrm{ml}$ and $0.5 \mathrm{mg} / \mathrm{ml}$ of betamethasone and clotrimazole, respectively was prepared as follows: $100 \mathrm{mg}$ of betamethasone was dissolved in $100 \mathrm{ml}$ diluent (Solution A), $50 \mathrm{mg}$ of clotrimazole was dissolved in $10 \mathrm{ml}$ diluent (Solution B). Then, $5 \mathrm{ml}$ of Solution A and $10 \mathrm{ml}$ of Solution B was diluted to $100 \mathrm{ml}$ with diluent.

The sample was prepared by weighing $5.0 \mathrm{~g}$ of the cream which is equivalent to $5.0 \mathrm{mg}$ of betamethasone and $50.0 \mathrm{mg}$ of clotrimazole in a100 ml-beaker, and then an adequate volume of diluent was added with stirring until homogeneous solution was obtained. The solution was transferred to a $100 \mathrm{ml}$ volumetric flask and the volume was completed to $100 \mathrm{ml}$ with diluent.

*Corresponding author: Adnan Manassra, Faculty of Science and Technology, Al-Quds University, P.O. Box 20002, East Jerusalem, E-mail: amanassra@yahoo. com

Received August 30, 2010; Accepted October 11, 2010 Published December 30,2010

Citation: Manassra A, Khamis M, el-Dakiky M, Abdel-Qader Z, Al-Rimawi F (2010) Simultaneous HPLC Analysis of Betamethasone and Clotrimazole in Cream Formulations. Pharm Anal Acta 1:113. doi:10.4172/2153-2435.1000113

Copyright: (c) 2010 Manassra A, et al. This is an open-access article distributed under the terms of the Creative Commons Attribution License, which permits unrestricted use, distribution, and reproduction in any medium, provided the original author and source are credited. 


\section{Solutions for validation study}

Linearity and range: Stock standard solution having $0.5 \mathrm{mg} / \mathrm{ml}$ and $5.0 \mathrm{mg} / \mathrm{ml}$ of betamethasone and clotrimazole, respectively was prepared by dissolving $50 \mathrm{mg}$ of betamethasone and $500 \mathrm{mg}$ of clotrimazole in $100 \mathrm{ml}$ diluent. Five different concentrations of betamethasone and clotrimazole were prepared from the sock solution as follows: $5 \mathrm{ml}$ of stock solution was diluted to $100 \mathrm{ml}$ with diluent $(0.025 \mathrm{mg} / \mathrm{ml}$ of betamethasone and $0.25 \mathrm{mg} / \mathrm{ml}$ of clotrimazole), $15 \mathrm{ml}$ of stock solution was diluted to $200 \mathrm{ml}$ with diluent $(0.0375 \mathrm{mg} / \mathrm{ml}$ of betamethasone and $0.375 \mathrm{mg} / \mathrm{ml}$ of clotrimazole), $10 \mathrm{ml}$ of stock solution was diluted to $100 \mathrm{ml}$ with diluent $(0.05 \mathrm{mg} / \mathrm{ml}$ of betamethasone and $0.5 \mathrm{mg} / \mathrm{ml}$ of clotrimazole), $25 \mathrm{ml}$ of stock solution was diluted to $200 \mathrm{ml}$ with diluent $(0.0625$ $\mathrm{mg} / \mathrm{ml}$ of betamethasone and $0.625 \mathrm{mg} / \mathrm{ml}$ of clotrimazole), and $15 \mathrm{ml}$ of stock solution was diluted to $100 \mathrm{ml}$ with diluent $(0.075 \mathrm{mg} / \mathrm{ml}$ of betamethasone and $0.75 \mathrm{mg} / \mathrm{ml}$ of clotrimazole).

Accuracy (Recovery): For recovery study, the placebo of the cream formulation was prepared according to the formulation procedure. Then, to the required quantity of the placebo, a known quantity of betamethasone and clotrimazole was added to get three concentration levels of betamethasone and clotrimazole $(50 \%, 100 \%$, and $150 \%$ of the working concentration of betamethasone and clotrimazole).

\begin{tabular}{|l|l|l|}
\hline & \% recovery \\
\hline Concentration level & Betamethasone & Clotrimazole \\
\hline 50 & 99.6 & 101.0 \\
\hline 100 & 100.3 & 100.6 \\
\hline 150 & 98.6 & 99.8 \\
\hline & Average: 99.5 & Average: 100.5 \\
\hline
\end{tabular}

Table 1: percentage recovery of betamethasone and clotrimazole at three concentration levels.

\begin{tabular}{|l|l|l|}
\hline Day & \% Betamethasone & \\
\hline 1 & $98.3 \pm 0.86$ & \% Clotrimazole \\
\hline 2 & $98.6 \pm 0.59$ & $99.7 \pm 0.52$ \\
\hline 3 & $98.2 \pm 0.50$ & $98.3 \pm 0.65$ \\
\hline 4 & $99.2 \pm 0.62$ & $99.3 \pm 0.77$ \\
\hline 5 & $98.5 \pm 0.78$ & $98.6 \pm 0.34$ \\
\hline 6 & $99.3 \pm 0.89$ & $98.5 \pm 0.70$ \\
\hline
\end{tabular}

*Mean \pm R.S.D. for four samples

Table 2: Intermediate-precision of the method for analyzing betamethasone and clotrimazole in cream formulations.

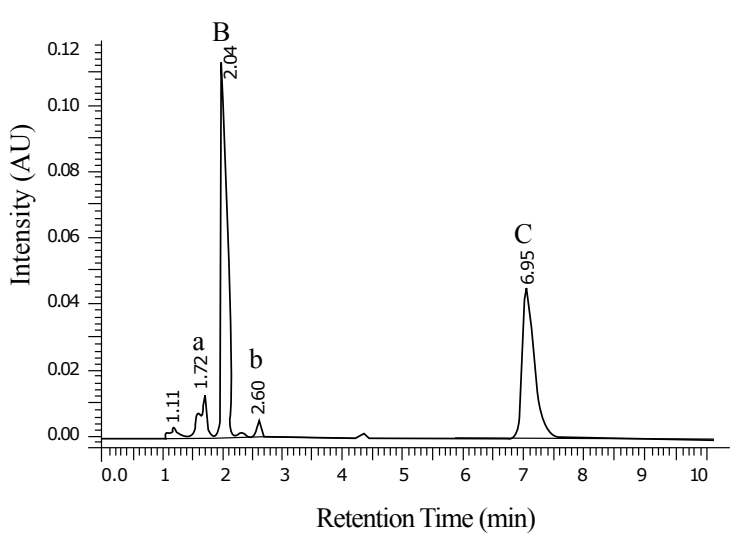

Figure 1: Typical chromatogram of pharmaceutical combination containinig $0.05 \mathrm{mg} / \mathrm{ml}$ of betamethasone, and $0.5 \mathrm{mg} / \mathrm{ml}$ of clotrimazole. Column: $\mathrm{C} 18$ $(25 \mathrm{~cm} \times 4.0 \mathrm{~mm}$ i.d). Mobile phase: methanol/buffer/acetonitrile $(33: 27: 40, \mathrm{v} / \mathrm{v})$. Flow rate: $1.5 \mathrm{ml} / \mathrm{min} ; \lambda: 254 \mathrm{~nm}$. Peaks identification, B: Betamethasone, C: Clotrimazole, a, b: Excipients from the cream preparation.

\section{Results and Discussion}

\section{Method development}

Reversed-phase LC-method was employed for the chromatographic separation of betamethasone and clotrimazole. To this end, reversed-phase C 8 and C18 columns using mixture of organic solvents (acetonitrile, and methanol) and aqueous buffer as a mobile phase was tested. While $\mathrm{C} 8$ column does not show enough resolution between these two analytes, $\mathrm{C} 18$ column shows adequate resolution. In order to optimize the chromatographic parameters, the effects of the buffer, methanol, and acetonitrile volume fractions on the separation of betamethasone and clotrimazole were studied. The optimum composition of the mobile phase was selected based on obtaining stable baseline, sharp peaks in reasonable time, and good separation of betamethasone and clotrimazole from each other and from the excipients present in the cream formulation. The selected composition was methanol/acetate buffer $(\mathrm{pH}=6.8) /$ acetonitrile with a ratio of $33: 27: 40$ by volume. A typical chromatogram of betamethasone and clotrimazole (prepared from the cream preparation) is shown in Figure 1.

\section{Method validation}

After method development, validation of the current method was performed in accordance with USP requirements for assay determination (Category-I: Analytical methods for quantitation of active ingredients in finished pharmaceutical products) which include accuracy, precision, selectivity, linearity and range.

Linearity and range: To evaluate linearity of the method, five calibration standards of betamethasone and clotrimazole containing 0.025 to $0.075 \mathrm{mg} / \mathrm{ml}$ of betamethasone and 0.25 to $0.75 \mathrm{mg} / \mathrm{ml}$ of clotrimazole were analyzed. A plot of peak area vs. amount injected was linear in the range of 0.025 to $0.075 \mathrm{mg} / \mathrm{ml}$ of betamethasone with a correlation coefficient of 0.9996 , and in the range of 0.25 to $0.75 \mathrm{mg} / \mathrm{ml}$ of clotrimazole with a correlation coefficient of 1.000 .

Accuracy (Recovery): Percentage recovery of betamethasone and clotrimazole using this method was determined by analyzing the three samples of the cream (prepared as in section 2.4.2) and the percentage of betamethasone and clotrimazole in the samples was calculated at the three concentration levels $(50 \%, 100 \%$, and $15 \%)$, by simple proportion from peak areas of the sample and a standard. Results have shown that the mean recovery of betamethasone and clotrimazole is within $100 \pm 2.0 \%$, see Table 1 .

Precision: Instrumental precision of this method was determined by injecting the standard solution of the two analytes six times. The RSD of peak areas of betamethasone and clotrimazole for the six replicates was found to be $0.73 \%$ and $0.52 \%$ for betamethasone and clotrimazole, respectively.

Intermediate-precision of the method was also evaluated by analyzing six samples of the two analytes at six days. Results which are represented in Table 1 show good intermediate-precision of the method (average percentage is $98.7 \%$ and $99.0 \%$ for betamethasone, and clotrimazole, respectively). Furthermore, RSD of the four samples was found to be less than $1.0 \%$, see Table 2 .

Selectivity: Selectivity of the current method was demonstrated by good separation of betamethasone and clotrimazole. Furthermore, betamethasone and clotrimazole are good separated from the excipients of the cream preparation as seen in Figure 1. 
Citation: Manassra A, Khamis M, el-Dakiky M, Abdel-Qader Z, Al-Rimawi F (2010) Simultaneous HPLC Analysis of Betamethasone and Clotrimazole in Cream Formulations. Pharm Anal Acta 1:113. doi:10.4172/2153-2435.1000113

\section{Conclusion}

The method represents a fast analytical procedure for simultaneous determination of betamethasone and clotrimazole in cream formulations with good accuracy, precision, reproducibility, linearity, selectivity, and reliability. The sample preparation is simple, and the elution is isocratic. The method is amenable to the analysis of large number of samples with excellent precision and accuracy.

\section{Acknowledgments}

We would like to thanks Jerusalem Pharmaceuticals Company for their encouragement, cooperation, help and providing all facilities.

\section{References}

1. Liu K, Chen S, Wu S, Kou H, Wu H (2004) HPLC determination of Betamethsone and Dexamethasone. J Chromatogr A 676: 455-460.

2. Massaccesi M (1986) Two-phase Titration of some Imidazole derivatives in pharmaceutical preparations; Analyst 111: 987-989.

3. British Pharmacopoeia Commission Office, British Pharmacopoeia 1998, the stationary office limited, London P 369.

4. Sawyer PR, Brogden RN, Pinder RM, Speight TM, Avery (1975) Clotrimazole: a review of its antifungal activity and therapeutic efficacy. Drugs 9: 424-447.

5. Lehne RA, Crosby LJ, Hamilton DB, Moore LA (1990) Pharmacology WB Saunders Company 746.

6. The United States Pharmacopoeia (1995) The National Formulary USP-23NF18 Pharmacopeial Convention, Inc Rockville 187.
7. Wang L, Yang YY, Chung TS, Chen XQ (2002) Determination of betamethasone disodium phosphate in the in-vitro media of PLGA microspheres by highperformance liquid chromatography. J Pharm Biomed Anal 28: 629-635.

8. Wallace SM, Shah VP, Riegelman S, Epstein WL (1978) Electron capture Gas Chromatographic assay for Miconazole and Clotrimazole in skin samples. Anal Lett B 11: 461-468.

9. Vaidya VV, Menon SN, Singh GR, Kekare MB, Choukekar MP (2007) Simultaneous HPTLC determination of clotrimazole and tinidazole in a pharmaceutical formulation. J Planar Chromator Modern TLC 20: 145-147.

10. Hamoudova R, Pospisilova M, Kavalirova A, Solich P, Sicha J (2006) Separation and determination of clotrimazole, methylparaben and propylparaben in pharmaceutical preparation by micellar electrokinetic chromatography. J Pharm Biomed Anal 40: 215-219.

11. Cavrini V, Di Pietra AM, Raggi MA (1982) HPLC analysis of imidazole antifungals in commercial dosage forms. Int J Pharm 10: 119-124.

12. Hoogerheide JG, Strusiak SH, Taddei CR, Townley ER, Wyka BE (1981) HPLC determination of Clotrimazole in pharmaceutical formulations. J Assoc Off Anal Chem 64: 864-869.

13. Guifang W, Xia S, Shouyao Z, Lihong Z (1996) Determination of Clotrimazole and Dyclonine $\mathrm{HCl}$ in compound Clotrimazole cream by HPLC. Zhongguo Yiyuan Yaoxue Zazhi 16: 66-67.

14. Tendolkar NM, Desai BS, Shinde VM (1994) Simultaneous determination of Tinidazole and Clotrimazole from tablets by RP-HPLC. Indian Drugs 31: 551 553

15. The United States Pharmacopoeia (2009) The National Formulary Pharmacopeial Convention Inc Rockville. 